\title{
実地医家における嗅覚障害診断手順
}

小林 正佳

三重大学大学院医学系研究科耳鼻咽喉・頭頸部外科

\section{Clinical diagnosis of olfactory dysfunction for the otolaryngologist}

Masayoshi Kobayashi

Department of Otorhinolaryngology-Head and Neck Surgery, Mie University Graduate School of Medicine

近年, 嗅覚, 味覚に関する社会的関心が高まり, 嗅覚障害を訴えてわれわれ耳鼻咽喉科を受診する 患者が増加している。その一方で，われわれ耳鼻咽喉科医は，どの診療施設においても嗅覚障害に対 する診療体制が十分にできているかといえば，必ずしもそうとは言い切れないのではないだろうか。 特に嗅覚障害の原因, 病態の診断に苦慮する症例は決して少なくない。ところが, 現時点で嗅覚障害 診療のガイドラインは残念ながらまだ確立されていない。そこで, この臨床セミナーでは, 現在の嗅 覚障害の診療における診断手順を解説する。

嗅覚障害の診断において，まず最初に行う問診は重要である。的確に問診することにより，原因， 障害程度, 日常生活への影響など診療に必要な情報を得る。実際に, 感冒後嗅覚障害では, 明らかな 器質的異常所見が認められず, 感眉歴の問診が診断の決め手となる。次に, 嗅覚障害の原因検索を行 う。嗅覚レセプターは鼻腔内の内側上部に位置する嗅裂部粘膜に局在しており，ファイバースコープ 検査でこの部位とここに至る気流路に異常所見がないかを確認する。嗅覚障害の原因疾患として最も 多い鼻・副鼻腔炎をはじめ, 鼻・副鼻腔内の病態を単純レントゲン写真で確認し, 必要に応じて CT スキャンでも確認する。頭部外傷や脳変性疾患など, 嗅球から脳に至る中枢性嗅覚障害を疑う例には MRI を施行する。

また, 障害程度の判定は嗅覚機能検査で行う。日本で医療保険が適用されている検査は, $\mathrm{T} \& \mathrm{~T} 才$ ルファクトメータを用いた基準嗅力検査とアリナミン注射液を用いた静脈性嗅覚検査の 2 種類のみで ある。基準嗅力検査は嗅覚域值の判定に有用であるが, 操作の煩雑性と室内のにおい拡散污染などが 理由で施行率が良くない。静脈性嗅覚検査の結果は予後とよく相関し, 予後判定検査として有用であ るが, 嗅覚能力の程度を判定する検査ではないことに注意が必要である。嗅覚同定能力検査としてス ティック型嗅覚検査とその改良版であるオープンエッセンスがある。簡便性に優れ, 臨床用検査とし ての有用性も確認されている。ただし現時点で医療保険適用が認められていない。嗅覚検査の低普及 に対して「日常のにおいアンケート」が開発された。ただしこれは問診に基づく補助手段である。本 来は常備されるべきである基準嗅力検査が普及していない現状において, 実地医家はどこまで嗅覚障 害の診断ができるのか, これを考えるセミナーとしたい。 